\title{
The Effect of Various Local Dances on Prospective Physical Education Teachers' Attitudes towards the Folk Dance Course
}

\author{
Meryem Altun ${ }^{1} \&$ Murat Atasoy $^{2}$ \\ ${ }^{1}$ School of Physical Education and Sports, Niğde Ömer Halisdemir Üniversity, Turkey \\ ${ }^{2}$ School of Physical Education and Sports, Ahi Evran Üniversity, Turkey \\ Correspondence: Meryem Altun, School of Physical Education and Sports, Niğde Ömer Halisdemir Üniversity, \\ Turkey. E-mail: mrymltn@hotmail.com
}

Received: November 24, 2018

Accepted: December 21, 2018

Online Published: January 7, 2019

doi:10.5430/ijhe.v8n1p19

URL: https://doi.org/10.5430/ijhe.v8n1p19

\begin{abstract}
In this study, the effect of various local dances on prospective physical education teachers' attitudes towards the folk dance course was examined. The research was conducted by using an experimental design with pre-test/post-test control group. A total of 46 female students, which includes an experimental group consisting of 23 students attended the folk dance class and a control group consisting of 23 students did not attend the folk dance class, who are studying at Niğde Ömer Halisdemir University, School of Physical Education and Sports in the Department of Teaching in the spring term of the 2017-2018 academic year and who are aged 20 years, voluntarily participated in the study. In this research, the Folk Dance Course Attitude Scale for Prospective Physical Education Teachers developed by Turan (2015) was used. In the experimental group, the folk dances training program, which continues for 14 weeks with the program of 2 days of a week for 2 hours at each day, was conducted. The data were analyzed by using SPSS 22 (Statistical Package for the Social Sciences) package program. In the analysis of data, dependent sampling t-test was used for examining the differences between experimental and control groups. As a result of the research, it was observed that there was a significant difference in favor of students who took the folk dance training. This result shows that various local dances are effective in developing a positive attitude towards this course.
\end{abstract}

Keywords: folk dances, folk dance course, physical education teaching

\section{Introduction}

The aim of education is to open new horizons in the minds of individuals, to make the individual being at peace with the learning and to educate the people who can giftedly transfer what they have learned into their life. Making people more competent in terms of psychological, sociological, cognitive, affective, and metacognitive aspects is the universal aim of education. Achieving these essential aims of education is impossible with the classical education approaches. In order for education make individuals to reach their goals, it should be based on experience and it should establish a personal connection between the individual and the subject of learning. The most valid method to establish this connection is to make the student more passionate in learning, to turn the moment of learning into a moment of happiness, and to provide more concrete experiences (Ulaş, 2014).

Plays are sometimes the building block of a competition, sometimes a sign of force, sometimes indispensable element of fun-filled moments. Plays always have the power to change the mentality shaped in our minds. Plays can make us more productive and innovative than we are. They can help us to understand the life better. When the plays are evaluated from the educational aspect, they are effective in providing new skills, which is the aim of all education programs, to individuals that can be called as universal skills such as "creative thinking, problem-solving, analytical thinking, interpretation, and communication" and that may influence their life directly (Gören, 2014).

The folk dances are " planned and regular movements, which reflect the cultural values of the society to which it belongs, which express an event, a happiness or a sadness, which is accompanied with the music (accompanied by a musical instrument or without a musical instrument by drumming with organs such as hands, feet etc.) that is performed by a single person or a group" (Eroğlu, 1999).

In his study, Aldemir (2010) clearly demonstrated the benefits of dancing activities in movement training of individuals in physical education and sports classes. McCormack (2001) stated that "Besides the development of physical skills and techniques, teaching dance also depends on the development of a series of artistic values and 
attitudes that are not always accessible in sports. Dance involves artistic, physical, mental, and emotional functions for individuals." (Cited by Demirel, 2012). The teacher promotes and encourages positive attitudes, confidence, and self-talk to maintain the dancer's success (Kassing and Jay,2003). If the student finds a topic serving her/his own purposes, it is expected from her/him to show more positive affective features for this subject, and if she/he considers the subject to be inappropriate or irrelevant to this purpose, she/he will be expected to show negative affective features and even expressly oppose it (Bloom, 2012).

Usta (2008) explicates the learning as "It shows that with the help of environmental interaction, the individual creates her/his own behavior change through her/his life experiences and it affects an individual's thoughts, feelings, attitudes, and beliefs.". An individual cannot react to events, facts, persons, and situations without developing an attitude towards them. Individuals behave according to tendencies, namely attitudes, based on pre-developed feelings and beliefs related to the events, facts, and circumstances (Özyürek, 2013). Behavior is an observable and measurable event performed by the organism. Behavior can be observed. Behavior can be measured because it has its own starting point, direction, and ending point (Fidan, 2012). Attitude is a phenomenon attained by learning, directing the individual's behavior, and causing bias in the decision-making process. In general terms, attitude is a biased reaction of the individual to a particular object (Ülgen, 1995). In his study, Bloom (2002) explicates that "Attitudes can be measured by using a list of questions (inventory) approaches that focus on opinions, thoughts, and tastes about this course starting from having a positive attitude towards a course, showing positive affective input characteristics in relation to it to showing negative affective input characteristics."

Concentration and attention during performing the dance steps of the folk dances increase performance. Children learn by curiosity and desire to move. The folk dance activities, which are included in the educational processes, enable children to use their creativity and allow them to recognize themselves. It is an important activity that should be in the lives of individuals because it supports children's developmental areas and provides an opportunity for their own experiences.

In many studies, based both on practice and observation, the importance of the folk dances training was emphasized in physical education teaching and the other related departments of universities, however, studies related to the folk dances were rarely seen. In future studies, it will be possible to direct new projects and services by determining the attitudes towards the folk dance course in the relevant teaching departments of universities and revealing the data that may constitute a basis for educational policy and planning.

In this respect, attitudes of the physical education teaching department's students were aimed to be measured with the thought that the student years are important periods for prospective physical education teachers in developing an attitude towards the folk dance course. The aim of this study is to investigate the effects of various local dances on prospective physical education teachers' attitudes towards the folk dance course.

\section{Method}

\subsection{Research Model}

The research was carried out by using an experimental design with pre-test/post-test control group. In short, experimental researches are studies conducted to test the effect of differences created by the researcher on the dependent variable (Büyüköztürk vd., 2012).

\subsection{Study Group}

A total of 46 female students, which includes an experimental group consisting of 23 students attended the folk dance class and a control group consisting of 23 students did not attend the folk dance class, who are studying at Niğde Ömer Halisdemir University, School of Physical Education and Sports in the Department of Teaching in the spring term of the 2017-2018 academic year and who are aged 20 years, voluntarily participated in the study.

\subsection{Data Collection Tools}

The Folk Dance Course Attitude Scale for Prospective Physical Education Teachers developed by Turan (2015) was used in the research. The Cronbach's Alpha reliability coefficient of the scale was .94. In the experimental group, the folk dances training program, which continues for 14 weeks with the program of 2 days of a week for 2 hours at each day, was conducted. The local dances selected from various regions such as Aegean (Harmandal, Çökertme, Yörük Ali), Black Sea (Trabzon), Central Anatolia (Niğde) and Eastern Anatolia (Van Halayı/ Folk Dance of Van) were applied. 


\subsection{Analysis of Data}

The obtained data were examined by using SPSS 22 (Statistical Package for the Social Sciences) package program. Primarily, arithmetic means of all test results of the experimental and control groups were calculated and recorded in the SPSS program. In order to analyze the differences between the experimental and control groups, dependent sample t-test was used in the analysis of data.

\section{Findings}

Table 1. Pre-test/Post-test t-test Results of the Experimental Group

\begin{tabular}{|c|c|c|c|c|c|c|}
\hline Group & $\mathbf{N}$ & $\mathbf{X}$ & Ss & Sd & $\mathbf{t}$ & $\mathbf{p}$ \\
\hline Experimental Pre-test & 23 & 4,43 & ,484 & 44 & 3,754 & ,001 \\
\hline $\begin{array}{l}\text { Experimental } \\
\text { Post-test }\end{array}$ & 23 & 4,87 & ,289 & & & \\
\hline
\end{tabular}

As seen in Table-1, there is a statistically significant difference between the pre-tests and post-tests of the experimental group.

Table 2. Pre-test/Post-test t-test Results of the Control Group

\begin{tabular}{|c|c|c|c|c|c|c|}
\hline Group & $\mathbf{N}$ & $\mathbf{X}$ & Ss & Sd & $\mathbf{t}$ & $\mathbf{p}$ \\
\hline Control Pre-test & 23 & 2,83 & 1,30 & 44 & , 000 & 1,00 \\
\hline Control Post-Test & 23 & 2,83 & 1,30 & & & \\
\hline
\end{tabular}

As seen in Table-2, there is no statistically significant difference between the pre-tests and post-tests of the control group.

\section{Discussion and Results}

The folk dance course is in the category of restricted elective courses in Niğde Ömer Halisdemir University, School of Physical Education and Sports in the Department of Teaching. Therefore, some students have negative opinions about this course. One of the reasons for these opinions is that this course is unnecessary for some of them. Accordingly, it was observed that students' attention, interest, and motivation were low in this course. Some of them stated that they were not talented, had no ear for music, and felt shy of dancing in public. In order to change this negative attitude, various teaching methods were covered in the folk dance courses and various local dances were preferred. As a result of the study, a statistically significant difference was observed between the pre-test and post-test of the experimental group, while there was no statistically significant difference between the pre-test and post-test of the control group. This result demonstrates that selecting various local dances are effective in developing a positive attitude towards this course.

According to the results of the study conducted by Atasoy et al. (2018), in terms of visual-motor perception levels, a significant difference in favor of the experimental group was found between the seven-year-old children attending a folk dances class and the seven-year-old children receiving education in accordance with the Education Program of the Ministry of National Education. This result indicates that folk dances are effective in improving the visual-motor perception level. There was also no significant difference in terms of gender.

According to results of the study on problem-solving skills of university students engaged in playing football and dancing conducted by Pehlivan and Öksüzoğlu (2006), providing the skills such as questioning, making analysis and synthesis, problem-solving, making a judgment, and criticizing to the individuals is one of the responsibilities of the education. It is understood that movement and sport training activities, which are a tool of education, prepare a highly suitable environment to individuals for grouping, analyzing, developing hypotheses, reaching synthesis, and obtaining mental skills such as problem-solving. These mental skills can only be attained through the participation of 
the student in research and problem-solving processes in the learning environment. In movement training, which has a wide usage of vocabulary, the ability of the individual to use the problem-solving method can be transformed into an enjoyable activity with a good orientation. Therefore, it is understood that sports environments such as dance and football, in which children and young people fondly participate, develop the thinking skills of the children. Encouraging the participation of children and young people in such activities is also important for their general education.

\subsection{Suggestions}

In future studies, it will be possible to direct new projects and services by determining the attitudes of prospective physical education teachers towards the folk dance course and revealing the data that may constitute the basis for educational policy and planning.

The fact that the sample of the study is few in number and that the participants are collected from a single university restrict the generalization of the research results. The number of participants can be increased, the working period can be kept longer, and a more comprehensive study in the field can be conducted.

\section{References}

Aldemir, G. Y. (2010). Drama ve dans eğitiminin 10-14 yaş çocuklarda motor özelliklerin gelişsimine etkisinin incelenmesi. (Yüksek Lisans Tezi). Marmara Üniversitesi Sağlık Bilimleri Enstitüsü Beden Eğitimi ve Spor Anabilim dalı. İstanbul.

Atasoy, M., Altun, M., Yalçınkaya, A. (2018). Halk oyunlarının ilkokul birinci sınıf (7 yaş) öğrencilerinin görsel motor alg1 düzeylerine etkisinin incelenmesi. Turkish Studies Educational Sciences, 13(19), 119-126. https://doi.org/10.7827/TurkishStudies.13864

Bloom, S. B. (2012). İnsan nitelikleri ve okulda öğrenme. (Çev: D. A. Özçelik) (2. Baskı). Ankara: Pegem Akademi.

Büyüköztürk, Ş., Kılıç Ç., E., Akgün, Ö.E., Karadeniz, Ş., Demirel, F. (2012). Bilimsel Araştırma Yöntemleri. Ankara:Pegem Akademi.

Demirel M. (2012). Beden eğitimi öğretmenlerinin halk danslarına yönelik tutumları. (Yüksek Lisans Tezi). Kırıkkale Üniversitesi Sağlık Bilimleri Enstitüsü. Kırıkkale.

Eroğlu, T. (1999). Halk oyunları el kitabı. İstanbul: Mars.

Fidan, N. (2012). Okulda öğrenme ve öğretme (3. Baskı). Ankara: Pegem Akademi.

Gören, E. (2014). Zeka oyunlart. İstanbul: Favori.

Kassing, G. Jay, D. M. (2003). Dance teaching methods and curriculum design. Northern Illinois University. Human Kinetics.

Özyürek, M. (2013). Engellilere yönelik tutamların değiştirilmesi (4. Basım). Ankara: Kök Yayıncılık.

Turan, Z. (2015). Beden eğitimi öğretmen adayları için halk oyunları dersi tutum ölçeğinin geliştirilmesi. $Y Y \ddot{U}$ Eğitim Fakültesi Dergisi (YYU Journal Of Education Faculty), 12(1);202-222. ISSN:1305-2020.

Pehlivan, Z., Öksüzoğlu, P. (2006, 3-5 Kasım). Futbol ve Dansla Uğraşan Üniversite Öğrencilerinin Problem Çözme Becerileri. 9. Uluslararası Spor Bilimleri Kongresinde Sunuldu, Muğla.

Ulaş, H. (2014). Drama, oyun ve fiziki etkinlikler. İstanbul: Favori.

Usta, İ. (2008). Öğrenme stillerine göre düzenlenen beyin temelli ögrrenme uygulaması. (Yüksek Lisans Tezi) Süleyman Demirel Üniversitesi Sosyal Bilimler Enstitüsü Eğitim Bilimleri Anabilim dalı. Isparta.

Ülgen, G. (1995). Eğitim psikolojisi - birey ve öğrenme. Ankara: Bilim Yayınları. 